\title{
AXL Gene Mutation
}

National Cancer Institute

\section{Source}

National Cancer Institute. AXL Gene Mutation. NCI Thesaurus. Code C141276.

A change in the nucleotide sequence of the AXL gene. 